\title{
Henry Constable's sonnets to Arbella Stuart
}

\author{
Mã Jesús Pérez Jáuregui \\ U niversity of Sevilla
}

\begin{abstract}
Although the Elizabethan poet and courtier Henry Constable is best known for his sonnet-sequence Diana (1592), he also wrote a series of sonnets addressed to noble personages that appear only in one manuscript (Victoria and Albert Museum, MS Dyce 44). Three of these lyrics are dedicated to Lady Arbella Stuart cousin-german to James VI of Scotland-, who was considered a candidate to Elizabeth's succession for a long time. Two of the sonnets were probably written on the occasion of Constable and Arbella's meeting at court in 1588, and praise the thirteen-year old lady for her numerous virtues; the other one seems to have been written later on, as a conclusion to the whole book, implying that Constable at a certain moment presented it to Arbella in search for patronage and political protection. At a time when the succession seemed imminent, Constable's allegiance to the Earl of Essex, who befriended A rbella and yet sent messages to James to assure him of his circle's support, raises the question of the true motivation of these sonnets. This paper will analyze these particular works in the context of a political environment rife with courtly intrigue.
\end{abstract}

KEYwords: Henry Constable, A rbella Stuart, Elizabethan sonnets, Succession debate, Elizabeth I's Court.

Henry Constable (1562-1613), poet, polemicist and diplomat, is best known for his Diana, first published in 1592, and one of the first sonnet sequences printed in England. Besides this edition and a second, augmented quarto (1594), there are also several manuscripts containing some of his works; one of these, Victoria and Albert MS Dyce 44 -also known as the Todd manuscript- includes a group of sonnets dedicated to particular persons. ${ }^{1}$ They are organized in four

${ }^{1}$ Besides the Todd there are other interesting manuscripts containing poems by Constable: the Marsh MS, at the Marsh Library, Dublin (MS z.3.5.21); the Harington

(5) ederi19 (2009): 189-202

https://doi.org/10.34136/sederi.2009.9 
series of seven, located in the second and third sections of the book: ${ }^{2}$ the first group praise the Queen of England and the King of Scotland; the second celebrate several ladies of high rank; the third were written to be presented on specific occasions; and the fourth, in which two sonnets are missing, are funeral poems. Two of the sonnets in the second subsection, plus one more placed at the end of the book as a sort of colophon, are addressed to Lady Arbella Stuart, who was considered a potential heir to Elizabeth's throne. ${ }^{3}$ Since these poems were written at a time of intense political intrigue, when different personages of the court were striving to win the favour of one of the candidates for the succession, the analysis of their meaning and political purpose can shed light on the way in which a gentleman poet like Constable, of moderate means and rank, attempted to negotiate this uncertain situation.

Lady Arbella Stuart (1575-1615) was a descendant of Margaret, Henry VIII's elder sister who was married twice, first to James IV of Scotland, from which union Mary Queen of Scots and ultimately James VI of Scotland would descend; and second to Archibald Douglas, Arbella being their great-granddaughter. ${ }^{4}$ Due to this distinguished ancestry, her claims to the throne were strong, and her cousin-german James was her chief rival for the succession. An important fact that favoured Arbella's aspirations was her being English in birth and upbringing, while James was regarded as a foreigner. This complicated James's position. As Paulina Croft points out, no foreigner could inherit English lands under the English statute of 1531, so inheriting the crown was theoretically out of the question (2002: 43); and Henry VIII had "explicitly debarred the Scottish line descended from his sister Margaret" in his will (2002: 44). Moreover, to the English collective mind, foreigners were suspect, not only for religious reasons -their participation in Catholic

MS, at Arundel Castle; and MS Ashmole 38, at the Bodleian Library, Oxford (Grundy 1960: 86-91).

${ }^{2}$ This division follows Constable's own arrangement, explained by the author, in an address placed between the prefatory poems and the beginning of the first section (Grundy 1960: 114).

${ }^{3}$ These three sonnets are "That worthie Marquesse pride of Italie", "Only hope of oure age that vertues dead", and "My Mistrisse worth gave wings unto my Muse."

${ }^{4}$ Her parents were Charles Stuart, earl of Lennox (1555/ 6-1576), and Elizabeth (1554?-1582), daughter of Sir William Cavendish and his third wife, Elizabeth, née Hardwick, who would later become Countess of Shrewsbury. 
plots and wars during the 1580s and 1590s, some contemplating endangerment and invasion of the realm, rendered them threats "from within" and "from without" (Marienstras 1985: 102)- but also for economic reasons, given the natural English jealousy of their own rights and liberties, from which they did not want foreigners to benefit (1985: 103-104). The possibility that James would bring about an assimilation of Scottish people as subjects with the same status as the English was certainly viewed with suspicion.

However, her gender counted against Arbella. According to John Bruce, many people disliked the prospect of "another long female reign." Her lack of a firm religious identity was also a source of some concern (1861: 14-15). Little by little, even though Elizabeth had forbidden her subjects to discuss the issue, people tended to assume that James would succeed. Only on one occasion had Elizabeth hinted that A rbella was a potential queen; according to her biographers, the Queen told the French ambassador: "Look to her well: she will one day be even as I am and a lady mistress" (Durant 1978: 46).

In 1587 twelve-year-old Arbella, who had lost her parents and was provided for by her grandmother Elizabeth Cavendish, best known as Bess of Hardwick, visited court for the first time. As Joan Grundy states, Constable may have spent the main part of the years 1588 and 1589 at court, taking a break from his various travels as a diplomat and champion of Protestantism. ${ }^{5}$ They may have first met in the summer of 1588, before the events of the Armada, and all the indications are that they liked each other well. As Grundy observes, "in a letter of 1589 he [Constable] is described as not only 'near allied to' but 'in the company' of her" (1960: 26). In addition, they both had a family connection with Gilbert and Mary Talbot, who were in charge of A rbella for some periods of time. ${ }^{6}$

In the first two sonnets dedicated to her, Constable decided to praise the young Arbella chiefly for her intellectual accomplishments. Significantly, no reference is made to her

\footnotetext{
${ }^{5}$ He had already been to France, Italy, Poland and probably Germany and the Low Countries by this time (Sullivan 2004).

${ }^{6}$ Gilbert Talbot was Constable's second cousin on his father's side. Mary was Arbella's maternal aunt; therefore Constable and the young candidate to the throne were related.
} 
physiognomy. According to Durant, "had Arbella been a court beauty, many flatterers would have told us so." The French ambassador called her "sufficiently handsome in the face, which really was no compliment at all" (1978: 50). She probably was not physically outstanding by the standards of her age. However, all biographers agree -grounding their assessment on courtly letters and reports- that she was given the education of a queen, as her grandmother expected her to become nothing less. Arbella's uncle, Charles Cavendish, wrote in a letter to his mother that "Lord Burghley had spoken to Sir Walter Ralegh 'greatly in hir commendation', saying that she could speak Italian and French, played instruments, danced and sewed beautifully, and 'wished she weare 15 years old'" (Steen 1994: 20). Gristwood gives a more detailed account of this upbringing in her biography of Arbella, noting how "there was [...] a tradition of female learning in Arbella's family [...]. She was related to many of the 'learned ladies' of the day" (2004: 76). Lady Lennox, her grandmother, had written poetry, and her cousins, the daughters of the Talbots -Elizabeth, Mary and Alethea- became published authors (2004: 77). Other contemporaries such as Sir John Harington praised her education, her musical taste, her skill for languages and the contrasting "sobriety in her fashion of apparel and behaviour" (2004: 74).

This line of praise is condensed in the comparison Constable establishes between Arbella and Vittoria Colonna, Marchioness of Pescara (1490-1547), in the sonnet "That worthie Marquesse pride of Italie" (Grundy 1960: 148). ${ }^{7}$ This Italian gentlewoman wrote most of her poetry (Rime spirituali) after the death of her husband, and in her works she expressed her longing for a reunion with him. Pietro Bembo, Michelangelo, Baldassare Castiglione and other reputed artists of the time were among her literary friends, and she was also on intimate terms with many Italian Protestants. Numerous sonnets were written in her memory when she died.

Constable had been in Italy before 1588 and his acquaintance with this gentlewoman's writings most likely date from that time. He emphasises the "worth", "wit and phrase" of the Italian lady in the first half of the octave:

That worthie Marquesse pride of Italie

${ }^{7}$ All quotations from Constable's sonnets have been taken from this edition. 
Whoefor all worth and for her wit and phrase

Both best deserv'd, and best desert could prayse

Immortall Ladie is reviu'd in thee. (1-4)

He then proposes that Arbella's true worth can only be assessed by comparing her with this real woman of immense talent, instead of likening her to a goddess:

But thinke not strange that thy divinitie

I by some goddessetitle doe not blaze:

But through a woemans name thy glorie rayse,

For things vnlike of vnlike prayses be. (5-8)

He explains the choice of this comparison in the first half of the sestet, and finally states that, since Arbella's talents are beyond description, this sonnet can convey but an "earthly shadow" of her worth. Her qualities, he concludes, render her closer to heaven than to earth:

When we prayse men we call them gods, but when

We speake of gods weliken them to men:

Not them to prayse, but only them to knowe.

Not able thee to prayse, my drift was this:

Some earthlye shadowe of thy worth to showe,

Whose heauenly selfe aboue worlds reason is. (9-14)

In the sonnet following, "Only hope of oure age" (Grundy 1960: 149) he goes a step further and provides a more detailed account of Arbella's qualities of mind. Illustrating what the aforementioned courtiers had said or written about her, he begins by praising her fondness for learning in the first quatrain:

Only hope of oure age that vertues dead

By youre sweet breath should be reviu'd againe,

Learning discourag'd longe by rude disdaine

By youre white hands is only cherished. (1-4)

She is presented as the exception in a scenario in which learning has been long neglected, and the ambiguous placement of the word "only" helps the poet suggest both that she does not care about material things and that she is the only one truly preoccupied with learning. The motif of borrowing is then introduced in order to claim that those who want to praise her must borrow some of her own poetic genius as the only way to do it properly:

Thus others worth by yow is honoured: 
But whoe shall honoure youres? poore wits in vayne

We seeke to pay the debts which yow pertayne

Till from youre self some weal th be borrowed. (5-8)

A mong her many talents, the poet highlights her skill for languages -probably one of the traits that drew the attention of her contemporaries- and other intellectual gifts:

Lend some youre tongues that euery nation may

In his owne heare youre vertuose prayses blaz'd:

Lend them youre wit, youre iudgement, memorye,

Least they themselues should not knowe what to say. (9-12)

He and other wits are but debtors to Arbella: they cannot praise her properly without borrowing her talent. He concludes, likewise, that those who want to love her as well must borrow the poet's heart, which is now in Arbella's hands:

And that thow must belou'd as much as prays'd

My hearte thow mayst lend them, which I gaue thee. (13-14)

This ending adds a courtly expression of devotion which appears to be fairly conventional, as there is certainly no evidence of any romantic attachment between them. Arthur F. Marotti notes that "for [...] courtier poets, poems were an extension of artful, polite behavior and, at the same time, ways of formulating actual or wished-for social transactions" (1995: 9). The use of the language of love, exemplified in the last lines of this poem, related to the "culturally central issues of ambition, and social status" (1982: 397). Therefore, in the same way that many courtiers used conventional expressions of love to address the Queen in a quest for service and preferment, Constable tries to present his suit for patronage by turning Arbella into his mistress. ${ }^{8}$

Although it cannot be proved that Arbella wrote poetry, since no texts have been preserved, Steen argues that she was a "woman of letters", and she left abundant correspondence that was praised even by contemporary readers; one of them wrote: "she hath left a very well Enameld Picture of her self drawn by her own pen, wherein equal Commendation is to be given to the Easiness of stile,

${ }^{8}$ Constable also addressed three poems to the Queen at the beginning of section two using these same conventions. In fact, he repeatedly addressed every lady of rank to whom he dedicated a sonnet as a potential mistress, seeking social promotion and financial reward in return. 
and the quickness of her invention and phancy" (1994: 7). That Constable should focus on Arbella's intel lectual accomplishments in these two sonnets, without even alluding to her lineage or rank, is significant. It not only adds value to his praise of her education, suggesting that it is the most valuable of all her high attributes; it also helps the author to draw a subtle link between him and the young lady, emphasising the fact that they are both writers, united by their love of poetry and learning.

Before proceeding to the third poem, which is set apart from the first two, wider discussion must be given to the political manoeuvres in which Constable was involved, in order to understand the importance of his sonnets. Constable was abroad in 1587, probably serving under the Earl of Leicester in the Low Countries (Grundy 1960: 24); he even wrote a pamphlet in early 1588 in which he condemns the attitudes of some Catholics during the course of the war, and makes a favourable assessment of Leicester's actions. ${ }^{9} \mathrm{His}$ loyalty to Leicester extended to his stepson, Robert Devereux, Earl of Essex, and Constable soon became a member of his circle. Essex was by this time the Queen's new favourite, and his influence at court made him a central figure in the intrigues surrounding the succession. It seems reasonable to infer, therefore, that Constable's movements and bids for patronage must have been affected by Essex's position.

There is evidence of Essex and Arbella's acquaintance dating from 1588; some biographers agree that they became friends: when A rbella was in trouble after publicly showing her pride and arousing the anger of some courtiers, Essex appeared and spoke up in her support (Gristwood 2004: 105; Lovell 2006: 355-356). ${ }^{10}$ Gristwood believes that he was only interested in defending her status, as "it is hard to envisage a man more sure to be chivalrously sympathetic

\footnotetext{
${ }^{9} \mathrm{~A}$ short vew of a large examination of Cardinall A llen his trayterous justification of Sir W . Stanley and $\mathrm{Y}$ orck, written by $\mathrm{Mr} \mathrm{H}$. Const., and this gathered out of his own draught. Extracts of this pamphlet are preserved in a commonplace book in the Marsh Library, Dublin (Grundy 1960: 24).

${ }^{10}$ As all the ladies and princesses went to chapel one day, Arbella claimed first place without the consent of the master of ceremonies -even though she probably deserved it by her rank-, angering everyone, including the Queen (Gristwood 2004: 103). Lovell adds that the Earl of Essex “came to Arbella's aid by 'saluting' her publicly when people stood aghast at such arrogance" (2006: 356).
} 
towards Arbella's attempt to claim pre-eminence as a princess of the blood" (2004: 105). ${ }^{11}$ Other biographers emphasise that this friendly attitude angered the Queen, who was jealous of her favourites; it even elicited rumours of a possible affair later in 1592, which according to Lovell were always angrily denied by Arbella (2006: 386). They seem to have remained friends until Essex's death (Lovell 2006: 386) and, even after that, Arbella remembered the earl with gratitude. Norrington quotes a fragment from a letter written by her in 1603:

And were I unthankfully forgetful if I should not remember my noble friend, who graced me, by her Majesty's commandment disgraced orphan, unfound ward, unproved prisoner, undeserved exile, in his greatest and happiest fortunes, to the adventure of eclipsing part of her Majesty's favours from him, which were so dear, so welcome to him? (2002: 68)

Despite his support for Arbella, Essex endorsed James of Scotland's candidature for the succession. Essex's first letters to James date from 1598, but much earlier he had assured the monarch of his loyalty. In 1589, Constable went on an errand to Scotland as part of "an intrigue to secure James VI's favour for the Earl of Essex" (Grundy 1960: 28). On October 29, Burghley's spies in Edinburgh reported that Constable had had meetings with the king, presenting to him letters and portraits of Penelope Rich, Essex's sister, and some other ladies of the Court. Grundy argues that "he had assured James that the friendship and alliance between Arbella and him did not lessen his loyalty to him" (1960: 29). It seems likely that this mission was motivated by a belief that Elizabeth would not live much longer, and the prominent men at court wanted to secure their positions in case James succeeded -and as time went by it was taken for granted he would. ${ }^{12}$ At this moment, however, James was busy enough with the preparations for his marriage, and Fowler, Burghley's intelligencer, told his master: "the best is Victor [James's code name] regards not their offers much" (Varlow 2007: 114-115). N evertheless,

\footnotetext{
${ }^{11}$ Lovell enumerates a series of personality traits that both Arbella and Essex shared, "both seeking great store by their noble birth, both erudite, both with a streak of hysteria never far below the surface, both potentially self-destructive, both all too apt, when things went wrong, to hurl wild accusations at a third party" (2006: 386).

${ }^{12}$ Fowler wrote that Penelope and Essex were giving "the poor king to hope for hap shortly, and that her majesty could not live above a year or two" (Varlow 2007: 113).
} 
as Varlow promptly adds: "Penelope's friendly overtures paid off handsomely. Essex was James's most trusted ally for the next decade" (2007: 115).

Taking into account these complex circumstances, Essex and Constable's familiarity with Arbella might have been politically convenient, as A rbella might yet become queen or reach a position of power through a marital alliance, even while they were intriguing to further James's claim. No official heir to the throne had been named, and securing a double allegiance made sense because uncertainty surrounded the whole issue of succession. Seeking her favour was therefore far from superfluous.

It was precisely Arbella's royal blood and her potential that motivated the composition of the third sonnet, very different in subject matter from the two that have been discussed. "My Mistrisse worth gave wings unto my Muse" (Grundy 1960: 179) is the very last poem in the Todd MS; it follows a "Conclusion of the whole" that includes a brief prose text in which Constable explains that he has decided to stop writing "vayne poems" and that he wants to "employe the remnant of wit to other calmer thoughts" (Grundy 1960: 178). The title, added to the sonnet by the manuscript compiler, reads as follows: "To the divine protection of the Ladie Arbella the author commendeth both his Graces honoure and his Muses aeternitye." As the actual conclusion to the selection of Constable's works in the MS, this poem must have been composed and added somewhat later than the other two. Since those were written around 1588 and, according to Grundy, "by the end of 1590 [...] Constable's secular sonnets were probably all written, and the definitive collection represented by the Todd MS made or about to be made" (1960: 33), this last sonnet may have been written between 1589 and early 1591.

The aim of the poem, as the title in the manuscript indicates, is to dedicate the whole work to Arbella, probably in order to give her a copy as a gift. This is made clear in line 5, in which the poet mentions "this booke which heare you may peruse." The importance of presenting manuscript copies of poems to people of rank in search of patronage has been emphasised by scholars such as Marotti and Jason Scott-Warren. The presentation of a copy was a "unique", prestigious gift in the context of patronage relations, something that could not be performed as successfully in print (Scott-Warren 2005: 
56). Manuscript circulation was preferred by "genteel, aristocratic or upwardly mobile individuals" to ensure that restricted readerships received their poetical texts (Marotti 2007: 16). Circulation and repeated modification enabled Constable and his contemporaries to rededicate whole series of poems to different personages. ${ }^{13}$

The poet and Arbella could hardly have met in 1591: Constable left England in the summer and A rbella was not back at court (after a three-year absence) until October the same year. However, it is very likely that this final sonnet was composed at this time. During her previous visits Arbella had "been played by the queen as a diplomatic card" (Durant 1978: 54), and the third visit was not an exception. In 1591, the marriage negotiations with the Duke of Parma -concerning the match between his son Rainutio Farnese and Arbella- were resumed with renewed emphasis. ${ }^{14}$ Rainutio's mother was descended from John of Gaunt, son of Edward III; as Durant notes, "this remote claim added to Arbella's undoubted right would have made the marriage acceptable to England" (1978: 43). Cecil, through his spy network, offered Parma a separate princedom in the N etherlands and of course, the certainty of having his son crowned king of England. Since this moment was "the nearest that Arbella ever came to a throne" (Durant 1978: 64), it makes sense that Constable should decide to dedicate a copy of his book to her.

The title of this final sonnet, in which the poet commends his "Grace's honour" to Arbella's protection, gives readers an important clue: Arbella is not the "Mistrisse" (line 1) for whom Constable has suffered; the name Grace may refer to Grace Talbot, Bess of Hardwick's daughter-in-law. Other poems in the sequence allude to this lady, and she probably was either "Diana" or a later love to whom the sonnets were rededicated. In the sonnet Arbella is regarded merely as a protector -all praise is taken for granted- given her social status and royal blood.

\footnotetext{
${ }^{13}$ It is interesting to note that the collection in the Todd MS begins with the sonnet "Grace full of grace", entitled "To his Mistrisse", in which Constable claims to dedicate the sequence to a lady, probably Grace Talbot, and ends with this rededication to Arbella.

${ }^{14}$ These negotiations had begun in 1587, at the time of Arbella's first appearance at court, but were interrupted by the war with Spain (Durant 1978: 41).
} 
The conceit of the poem revolves around the idea of flying likea bird:

My Mistrisse worth gaue wings vnto my Muse

And my Muse wings did giue vnto her name

So liketwin byrds my Muse bred with her fame

Together now doe learne theyre wings to vse. (1-4)

In these first lines the poet establishes a connection between his Muse, or the inspiration that has led him to write the sonnets, and his lady, whom he has given fame; both of them are "twin birds" ready to fly. The metaphor continues:

And in this book which heareyou may pervse

A broad they fly resolu'd to try the same. (5-6)

And it is in lines 7 and 8 that Constable manifests his desire for protection:

Adventure in theyreflight, and thee sweet dame

Both sheand I for oure protectoure chuse.

"She" is once again the poet's mistress.

Line 9 has clear socio-political allusions; the speaker states why he and Grace dare ask for this support:

I by my vow and she by farther right

Vnder your Phoenix [wing] presume to flye. (9-10)

According to Tom Parker, "by my vow" indicates that "possibly he had sworn some kind of political allegiance to her, for in 1589 it had been necessary to convince King James that his loyalty was in no doubt." He adds that "Grace's presence under the wing is allowed by 'farther right' which [...] may allude to their family connection, possibly with a pun on 'father' -Grace's father had married Arbella's grandmother" (1998: 162). In the lines following, Arbella's "wing" or protection is a shelter, a defence against the birds that feed on dead animals; this term may be referring to those people who wish -or do- Constable and his mistress harm, by tarnishing their reputation:

That from all carrion beakes in saftie might

By one same wing be shrouded she and I.

O happie if I might but flitter there

Where you and she and I should be so neare. (11-14) 
Mary Lovell describes Grace's husband Henry Cavendish as a man who spent little time with his wife, travelled extensively, and did not care about perpetuating the dynasty; in fact, he fathered numerous bastards. She remarks that "he once stormed at his wife before their servants that she was a harlot, which seems extremely unlikely behaviour for this mild-mannered, thoroughly dutiful woman" (2006: 489). Therefore, Grace may have had to suffer the slanders derived from her husband's unfaithfulness. This may have prompted the poet to appeal to A rbella to defend Grace's honour.

Besides the search for patronage or protection, which was customary among poets at court, there is one issue that adds some interest to this last sonnet under discussion. Constable had converted to Catholicism by the year 1590, and in 1591 he spoke of it publicly, becoming an exile in France. Religion was obviously a central, and controversial, issue in the debate on the succession. The author of a book printed in Antwerp in 1594 entitled A Conference about the $\mathrm{N}$ ext Succession to the Crowne of Ingland, presents his views on the matter by stating that Arbella's religion was "no great motive, either against her or for her", being "tender green and flexible yet, as is her age and sex" (quoted in Gristwood 2004: 145). Arbella's family, the Lennoxes, were Catholics and, according to Handover, "it was to be a turning point of A rbella's career when she was removed, by the death of her father and paternal grandmother, from Catholic influences before she was three years old" and raised as a Protestant (1957: 59). After the execution of Mary Queen of Scots in 1587, Arbella's religion became a crucial subject indeed. Handover argues that, "had she ever declared herself a Catholic she would have attracted support from Catholics at home and abroad" (1957: 73). However, it was generally thought she inclined to Catholicism, and English Catholics preferred her to James. Constable doubtlessly knew that his conversion would get him into trouble, and seeking A rbella's protection at this time was a reasonable move. At the same time, though, he kept in touch with friends and powerful men like Essex, in an attempt to continue serving his country "as far as was consistent with his religion" (Grundy 1960: 39).

After the Farnese marriage negotiations failed in late 1592, A rbella was locked up -lest she were kidnapped or involved herself in an inconvenient marriage- and no longer considered a serious 
candidate the succession; ${ }^{15}$ as Durant puts it, she "was replaced in the limbo where the queen preferred her to be" (1978: 76). However, at the time of the writing of these sonnets, Constable was a courtier with no title or high position of his own, and he did his best to secure the protection of those who were powerful. His career as Essex's emissary and supporter could grant him not only the friendship of a considerably large faction of the court, but also the sympathies of James, the favourite candidate for succession, to whom he also addressed some sonnets. His poems to Arbella probably sprung from blood ties and friendly attachment, and evolve from literary praise into a similar plea for patronage, in the hope that her high status will ensure that she remains a powerful woman at court -if not queen.

\section{References}

Bruce, John 1861. Correspondence of King James VI of Scotland. London: Camden Society.

Croft, J. Pauline 2002. Patronage, Culture, and Power: The Early Cecils. New Haven, Conn.-London: Published for the Paul Mellon Centre for Studies in British Art, the Yale Center for British Art [by] YaleUniversity Press.

Durant, David N. 1978. A rbella Stuart. London: Weidenfeld and Nicolson.

Gristwood, Sarah 2004. A rbella: England's Lost Q ueen. London: Bantam.

Grundy, Joan, ed. 1960. The Poems of Henry Constable. Liverpool: Liverpool University Press.

Handover, Phyllis Margaret 1957. A rbella Stuart, Royal Lady of Hardwick and Cousin to King James. London: Eyre \& Spottiswoode.

Lovell, Mary S. 2006. Bess of Hardwick: First Lady of Chatsworth. London: Abacus.

Marienstras, Richard 1985. New Perspectives on the Shakespearean World. Cambridge: Cambridge University Press.

Marotti, Arthur F. 1982. "'Love is not Love': Elizabethan Sonnet Sequences and the Social Order." ELH 49/ 2: 396-428.

Marotti, Arthur F. 1995. M anuscript, Print, and the English Renaissance Lyric. Ithaca: Cornell University Press.

${ }^{15}$ Philip II started to suspect the Duke of Parma, either because he had heard rumours or because the latter's reluctance to fight in France alarmed him, and decided that a new general must be sent to Flanders to replace him. The Duke died in December 1592 (Handover 1957: 96). 
M.J. Pérez Jáuregui

Marotti, Arthur F. 2007. "Print, Manuscripts, and Miscellanies." Eds. Patrick Cheney, Andrey Hadfield and Garret A. Sullivan Jr. Early M odern English Poetry. A Critical Companion. New York: Oxford University Press: 15-26.

Norrington, Ruth 2002. In the Shadow of the Throne: The Lady A rbella Stuart. London: Peter Owen.

Parker, Tom W.N. 1998. Proportional Form in the Sonnets of the Sidney Circle: Loving in Truth. Oxford: Clarendon Press.

Scott-Warren, Jason 2005. Early M odern English Literature. Cambridge: Polity Press.

Steen, Sara Jayne 1994. The Letters of Lady A rbella Stuart. New York: Oxford University Press.

Sullivan, Ceri 2004. "Constable, Henry (1562-1613)." Oxford Dictionary of $\mathrm{N}$ ational Biography. Oxford: Oxford University Press.

Varlow, Sally 2007. The Lady Penelope: The Lost Tale of Love and Politics in the Court of Elizabeth I. London: Andre Deutsch.

H ow to cite this note:

Pérez Jáuregui, Ma Jesús. “Henry Constable's sonnets to Arbella Stuart." SEDERI 19 (2009): 189-202

A uthor's contact: jauregui@us.es

Submission: 07/ 10/ 2008

A cceptance: 14/ 12/ 2008 